\title{
PENGARUH MODEL PEMBELAJARAN KOOPERATIF TIPE NUMBERED HEAD TOGETHER (NHT) TERHADAP HASIL BELAJAR MATEMATIKA SISWA KELAS VII SMP NEGERI 1 BANGKINANG
}

\author{
Astuti \\ Universitas Pahlawan Tuanku Tambusai, Jl. Tuanku Tambusai No.23, Bangkinang \\ astutimasnur@gmail.com
}

Submitted: 23-05-2017, Reviewed: 03-06-2017, Accepted: 22-08-2017

\begin{abstract}
This study aims to determine the effect of cooperative learning model, Numbered Head Together (NHT) toward the students' Mathematics achievement at VII grade SMP Negeri 1 Bangkinang in the academic year 2014/2015. This is a quasi-experimental studies (Quasi Experiment). The population in this study is VII grade SMP Negeri 1 Bangkinang consisting of 4 classes with the number of 140 students. On another hand, the sample in this study consisted of two classes totaling 65 students. In both these classes are given different treatment is experimental class using cooperative learning model Numbered Head Together (NHT), while grade control using conventional learning. Two classes were given the test results of the study result. Analysis of the data used in this research is descriptive analysis and inferential analysis. Based on test, the normality test results of study conducted with chi-square test. In the experimental group obtained $x_{\text {count }}^{2}=2.67$ and $x_{\text {table }}^{2}=11.070$, then $x_{\text {count }}^{2}<x_{\text {table experimental }}^{2}$ class table means the data were normally distributed. While the control derived class normality test $x_{\text {count }}^{2}=5.81$ and $x_{\text {table }}^{2}=11.070$ then $x_{\text {count }}^{2}<x^{2}$ table means the data control class also normally distributed. Because the data these two classes are normal, followed by the homogenity test of F-test and obtained $f_{\text {count }}=0.80$ and $f_{\text {table }} 1.84$ then $f_{\text {count }}<f_{\text {table }}$ means the second data is a homogeneous class. Then proceed with the t-test. Based on the analysis of data obtained $t_{\text {count }}=2.01$ and $t_{\text {table }}=1.67$ then $t_{\text {count }}>t_{\text {able }}$ so that it can be concluded that there are significant effect of cooperative learning model Numbered Head Together (NHT) towards the students' Mathematics' achievement at VII grade of SMP Negeri 1 Bangkinang.
\end{abstract}

\section{Keywords: Cooperative Learning model Numbered Head Together (NHT), Mathematics achievement.}

Abstak. Penelitian ini bertujuan untuk mengetahui pengaruh model pembelajaran kooperatif tipe Numbered Head Together (NHT) terhadap hasil belajar matematika siswa kelas VII SMP Negeri 1 Bangkinang tahun ajaran 2014/2015. Bentuk penelitian ini adalah eksperimen semu (Quasi Experiment). Populasi dalam penelitian ini adalah kelas VII SMP Negeri 1 Bangkinang yang terdiri dari 4 kelas dengan jumlah 140 siswa, sedangkan sampel dalam penelitian ini terdiri dari 2 kelas yang berjumlah 65 siswa. Pada kedua kelas ini diberikan perlakuan yang berbeda yaitu kelas eksperimen dengan menggunakan model pembelajaran kooperatif tipe Numbered Head Together (NHT) sedangkan kelas kontrol menggunakan pembelajaran konvensional. Dua kelas tersebut diberikan tes hasil hasil belajar. Analisis data yang digunakan dalam penelitian ini adalah analisis deskriptif dan analisis inferensial. Berdasarkan data tes hasil belajar dilakukan uji normalitas dengan uji chi-kuadrat. Pada kelas eksperimen diperoleh $x^{2}{ }_{\text {hitung }}=2,67$ dan $x^{2}$ tabel $=$ 11,070 maka $x^{2}$ hitung $<x^{2}$ tabel berarti data kelas eksperimen berdistribusi normal. Sedangkan uji normalitas kelas kontrol diperoleh $x^{2}$ hitung $=5,81$ dan $x^{2}$ tabel $=11,070$ maka $x^{2}{ }_{\text {hitung }}<x^{2}$ tabel berarti data kelas kontrol juga berdistribusi normal. Karena data kedua kelas tersebut normal maka dilanjutkan dengan uji homogenitas dengan uji-F dan diperoleh $f_{\text {hitung }}=0,80$ dan $f_{\text {tabel }}=1,84$ maka $f_{\text {hitung }}<f_{\text {tabel }}$ berarti data kedua kelas ini homogen. Kemudian dilanjutkan dengan uji-t. Berdasarkan analisis data diperoleh $t_{\text {hitung }}=2,01$ dan $t_{\text {tabel }}=1,67$ maka $t_{\text {hitung }}>t_{\text {tabel }}$ sehingga dapat diambil kesimpulan bahwa terdapat pengaruh model pembelajaran kooperatif tipe Numbered Head Together (NHT) terhadap hasil belajar matematika siswa kelas VII SMP Negeri 1 Bangkinang. 


\section{Kata Kunci: Pembelajaran Kooperatif Tipe Numbered Head Together (NHT), Hasil Belajar Matematika}

\section{PENDAHULUAN}

Hal yang sangat penting dan perlu diperhatikan dalam proses pembelajaran matematika adalah bagaimana seorang siswa dapat memahami konsep pelajaran matematika dengan baik bukan hanya sekedar hapalan. Apabila siswa sudah memahami konsep maka akan mudah baginya untuk mengikuti proses pembelajaran selanjutnya. Tidak semua pendidik yang bisa mengajarkan konsep matematika kepada siswanya. Sebagian besar guru matematika lebih menekankan mengahapal rumus kepada siswa. Inilah salah satu penyebab siswa takut dengan matematika yaitu banyaknya rumus matematika yang akan mereka hafal. Padahal itu semua tidak benar, yang harus siswa lakukukan hanyalah memahami konsep matematika itu sendiri.

Peranan guru sangat penting dalam proses belajar mengajar agar konsep yang ingin disampaikan terwujud. Guru mata pelajaran matematika dituntut mempunyai berbagai kompetensi dalam memberi pemahaman kepada siswa, apalagi diiringi dengan berkembangnya ilmu pengetahuan dan teknologi yang semakin maju, apabila guru tidak bisa mengikuti perkembangan tersebut maka dapat dipastikan bisa memberi dampak kepada dunia pendidikan. Harapan bagi siswa adalah bagaimana siswa tersebut dapat mencapai tujuan dari pembelajaran matematika dan memiliki kemampuan dalam memecahkan masalah matematika.

Untuk mewujudkan tujuan pembelajaran matematika, maka pembelajaran matematika harus mendapat penanganan yang serius. Namun penyelenggaraan matematika tidaklah mudah karena fakta menunjukkan bahwa para siswa mengalami kesulitan dalam mempelajari matematika, kesulitan ini menyebabkan siswa tidak menyukai pelajaran matematika dan akhirnya hasil belajar siswa menjadi rendah.

Hasil belajar matematika tidak hanya dipengaruhi oleh kurangnya penguasaan terhadap materi tetapi juga disebabkan oleh beberapa hal, diantaranya kurang variatif guru dalam penyampaian pembelajaran matematika. Dalam penyajian pembelajaran guru masih menggunakan pembelajaran konvensional yaitu pembelajaran yang biasa dilakukan guru secara terus menerus yaitu pembelajaran yang masih terpusat pada guru. Langkah-langkah pembelajaran yang dilakukan guru adalah menyiapkan kelas, memberi motivasi, menyajikan materi, memberikan contoh soal, kemudian siswa mencatat, dan setelah itu memberikan latihan-latihan soal yang terdapat pada buku 
paket yang disediakan oleh sekolah. Pembelajaran seperti ini kurang mampu melibatkan seluruh siswa untuk aktif dalam pembelajaran. Dengan demikian, suasana pembelajaran menjadi tidak kondusif sehingga siswa menjadi pasif dan pembelajaran di kelas menjadi tidak optimal. Nilai rata-rata siswa perlu ditingkatkan dengan menggunakan model pembelajaran inovatif yang dapat merangsang siswa berpartisipasi aktif dalam pembelajaran sehingga dapat memperoleh hasil belajar yang optimal, salah satunya dengan menerapkan model pembelajaran kooperatif tipe NHT.

Pembelajaran kooperatif tipe NHT merupakan salah satu tipe pembelajaran kooperatif yang menekankan pada struktur khusus yang dirancang untuk mempengaruhi pola interaksi siswa dan memiliki tujuan untuk meningkatkan penguasaan akademik. Tipe ini dikembangkan oleh Kagen (dalam Ibrahim, 2000: 28) dengan melibatkan para siswa dalam menelaah bahan yang tercakup dalam suatu pelajaran dan mengecek pemahaman mereka terhadap isi pelajaran tersebut. Menurut Hamdani (2011: 90) kelebihan pada model pembelajaran NHT yaitu: Setiap siswa menjadi siap semua untuk belajar, siswa dapat melakukan diskusi dengan sungguh-sungguh serta siswa yang pintar dapat mengaja ri siswa yang kurang pintar.

Menurut Slameto (2010: 2) Belajar ialah suatu proses usaha yang dilakukan seseorang untuk memperoleh suatu perubahan tingkah laku yang baru secara keseluruhan, sebagai hasil pengalamanya sendiri dalam interaksi dengan lingkungannya. Menurut Trianto (2011: 16) belajar diartikan sebagai perubahan pada individu yang terjadi melalui pengalaman dan bukan kerena pertumbuhan dan perkembangan tubuhnya atau karakteristik seseorang sejak lahir.

Menurut Ruseffendi (2005: 17) Dalam model konvensional, guru merupakan atau dianggap gudang ilmu, guru bertindak otoriter, guru mendominasi kelas. Guru mengajarkan ilmu, guru langsung membuktikan dalil-dalil, guru membuktikan contohcontoh soal. Sedangkan murid harus duduk rapi mendengarkan, meniru pola-pola yang diberikan guru menyelesaikan soal sehingga membuat siswa menjadi pasif. Model konvensional dapat diartikan sebagai metode pembelajaran tradisional atau disebut juga dengan metode ceramah, karena sejak dulu metode ini telah diguakan sebagai alat komunikasi lisan antara guru dan siswa dalam proses belajar mengajar.

Menurut Suprijono (2010: 54) pembelajaran kooperatif adalah konsep yang lebih luas meliputi semua jenis kerja kelompok termasuk bentuk-bentuk yang dipimpin oleh guru atau diarahkan oleh guru. Menurut Trianto (2011: 82-83) NHT atau 
penomoran berfikir bersama adalah merupakan jenis pembelajaran kooperatif yang dirancang untuk mempengaruhi pola interaksi siswa dan sebagai alternatif terhadap struktur kelas tradisional. Pembelajaran kooperatif tipe NHT ini merupakan salah satu tipe dari model pembelajaran kooperatif dengan menggunakan kelompok-kelompok kecil dengan jumlah anggota tiap kelompok 4-5 orang siswa secara heterogen. dalam mengajukan pertanyaan seluruh kelas, guru menggunakan struktur empat fase sebagai sintaks NHT, adapun sintak NHT sebagai berikut:

Fase 1 : Penomoran

Fase 2 : Mengajukan pertanyaan

Fase 3 : Berfikir bersama

Fase 4 : Menjawab

Tabel 6. Langkah-langkah Pembelajaran Tipe NHT

\begin{tabular}{|c|c|}
\hline $\begin{array}{c}\text { Tahapan } \\
\text { Pembelajaran } \\
\text { NHT }\end{array}$ & \multicolumn{1}{|c|}{ Kegiatan Pembelajaran } \\
\hline $\begin{array}{c}\text { Fase 1 : } \\
\text { Penomoran }\end{array}$ & $\begin{array}{l}\text { Guru membagi siswa ke dalam kelompok 3-5 orang dan } \\
\text { kepada setiap anggota kelompok diberi nomor antara 1-5. }\end{array}$ \\
\hline $\begin{array}{c}\text { Fase 2: } \\
\text { Mengajukan } \\
\text { pertanyaan }\end{array}$ & $\begin{array}{l}\text { Guru mengajukan sebuah pertanyaan kepada siswa. } \\
\text { Pertanyaan dapat bervariasi. Pertanyaan dapat amat spesifik } \\
\text { dan dalam kalimat tanya. }\end{array}$ \\
\hline $\begin{array}{c}\text { Fase 3 : Berfikir } \\
\text { bersama }\end{array}$ & $\begin{array}{l}\text { Siswa menyatukan pendapatnya terhadap jawaban pertanyaan } \\
\text { itu dan meyakinkan tiap anggota dalam timnya mengetahui } \\
\text { jawaban tim. }\end{array}$ \\
\hline Fase 4 : Menjawab & $\begin{array}{l}\text { Guru memanggil suatu nomor tertentu, kemudian siswa yang } \\
\text { nomornya sesuai mengacungkan tangannya dan mencoba } \\
\text { untuk menjawab pertanyaan untuk seluruh kelas. }\end{array}$ \\
\hline
\end{tabular}

(Sumber: trianto, 2011:82-83)

\section{METODE PENELITIAN}

Tempat penelitian ini adalah di SMP Negeri 1 Bangkinang. Adapun waktu penelitian ini adalah semester genap tahun ajaran 2014/2015. Bentuk penelitian ini adalah quasi experimen (eksperimen semu). Menurut Setyosari (2013: 45) penelitian eksperimen semu atau eksperimen quasi subjek penelitian dipilih secara random dimana setiap subjek memperoleh peluang sama untuk dijadikan subjek penelitian. Karakteristik yang diukur dalam penelitian ini adalah hasil belajar matematika siswa. 
Populasi yang digunakan dalam penelitian adalah siswa kelas VII SMP Negeri 1 Bangkinang tahun ajaran 2014/2015 yang terdiri dari 4 kelas dengan jumlah siswa sebanyak 140 orang. Sampel dalam penelitian ini terdiri dari dua kelas, yaitu kelas $\mathrm{VII}_{\mathrm{A}}$ yang merupakan kelas eksperimen dan kelas $\mathrm{VII}_{\mathrm{B}}$ yang merupakan kelas kontrol.

Sampel penelitian ditentukan berdasarkan sampling purposive karena penelitian ini menggunakan quasi exsperimental. Menurut Sugiyono (2012: 68) sampling purposive adalah teknik penentuan sampel dengan mempertimbangkan tertentu. Kemudian Menurut Sudjana (2002: 168) sampling purposive terjadi apabila pengambilan sampel dilakukan berdasarkan pertimbangan perorangan atau pertimbangan peneliti.

Pada sekolah ini terdapat tiga dua yang mengajar mata pelajaran matematika, maka alasan peneliti memilih kelas $\mathrm{VII}_{\mathrm{A}}$ dan $\mathrm{VII}_{\mathrm{B}}$ merupakan rekomendasi kepala sekolah sehingga kelas $\mathrm{VII}_{\mathrm{A}}$ dan $\mathrm{VII}_{\mathrm{B}}$ dipilih sebagai sampel penelitian karena peneliti melakukan wawancara dengan salah satu guru matematika kelas VII yaitu ibu Armaini, S.Pd, yang mana guru tersebut mengajar didua kelas yaitu kelas $\mathrm{VII}_{\mathrm{A}}$ dan kelas $\mathrm{VII}_{\mathrm{B}}$. Kemudian guru tersebut bersedia peneliti melakukan observasi di kelasnya. Pemilihan kelas $\mathrm{VII}_{\mathrm{A}}$ sebagai kelas eksperimen dan kelas $\mathrm{VII}_{\mathrm{B}}$ sebagai kelas kontrol berdasarkan diskusi peneliti dengan guru matematika tersebut.

Instrumen yang digunakan pada penelitian ini adalah tes hasil belajar dan lembar pengamatan. Soal tes hasil belajar berupa soal tes yang diberikan setelah tindakan untuk kedua kelas, yaitu kelas eksperimen dan kelas kontrol. Lembar pengamatan yang disediakan bertujuan untuk mengamati keterlaksanaan model pembelajaran NHT.

Statistik deskriptif yaitu kegiatan statistik yang dimulai dari menghimpun data, menyusun atau mengukur data, mengolah data, menyajikan dan menganalisa data angka guna memberikan gambaran tentang suatu gejala, peristiwa atau keadaan. Dalam penelitian ini tujuan dari analisis deskriptif adalah untuk mendiskripsikan data tentang aktivitas siswa dan guru selama proses pembelajaran. Nilai perkembangan pada tiap pertemuan dan data tentang ketuntasan belajar siswa.

Teknik analisis data yang digunakan dalam penelitian ini adalah analisis inferensial, yaitu menguji keberhasilan dengan hasil belajar sebelum dan hasil belajar siswa sesudah tindakan dengan menggunakan uji statistik yaitu tes "t". Namun, penggunaan tes " $\mathrm{t}$ " tersebut harus memenuhi dua syarat yaitu uji normalitas dan homogenitas. 


\section{HASIL DAN PEMBAHASAN (Kapital 12 pt bold)}

Pada penelitian ini diperoleh hasil belajar siswa dari kedua kelas, yaitu kelas $\mathrm{VII}_{\mathrm{A}}$ yang dijadikan sebagai kelas kontrol dan kelas $\mathrm{VII}_{\mathrm{B}}$ dijadikan sebagai kelas eksperimen dengan menerapkan model pembelajaran kooperatif tipe NHT. Penelitian ini dilaksanakan sebanyak 5 kali pertemuan, yaitu pada pertemuan pertama sampai pertemuan keempat diterapkan model pembelajaran kooperatif tipe NHT pada kelas eksperimen dan pembelajaran konvensional pada kelas kontrol. Sedangkan pertemuan kelima diberikan tes hasil belajar kepada kelas eksperimen dan kelas kontrol dengan materi tentang perbandingan dan aritmatika sosial dan yang bertindak sebagai guru pada kelas eksperimen dan kelas kontrol adalah peneliti dan sebagai observer di kelas adalah teman kuliah.

Dari data tes hasil belajar materi bilangan dan tes hasil belajar materi perbandingan dan aritmatika sosial yang telah dilaksanakan pada kedua kelas.Peningkatan hasil belajar siswa pada tes hasil belajar materi bilangan dan tes hasil belajar materi perbandingan dan aritmatika sosial. Jika dilihat ketuntasan klasikalnya pada kelas eksperimen lebih banyak dari kelas kontrol sehingga terdapat perbedaan yaitu $56,67 \%-43,33 \%=13,34 \%$.

Setelah diuji homogenitasnya, diperoleh kesimpulan bahwa kelas eksperimen dan kelas kontrol homogen, maka uji perbandingan dua rata-rata hasil belajar (uji-t) setelah diberikan perlakuan yang berbeda digunakan rumus t. Berdasarkan rata-rata dan varians kelas eksperimen dan kelas kontrol, maka diperoleh $t=2,01$. Dengan peluang (1- $\alpha$ ) dengan $\alpha=0,05$, maka peluangnya 0,95 , dengan derajat kebebasan $(\mathrm{dk})=\mathrm{n}_{1}+\mathrm{n}_{2}$ $-2=32+33-2=63$, maka digunakan dk yang mendekati 63 yaitu 60. Dengan dk 60 diperoleh $t_{\text {tabel }}=1,67$. Dari hasil perhitungan dan kriteria diatas dapat dijelaskan bahwa $t_{\text {hitung }}=2,01>t_{\text {tabel }}=1,67$, maka $\mathrm{H}_{0}$ ditolak dan $\mathrm{H}_{1}$ diterima. Artinya terdapat pengaruh yang signifikan antara hasil belajar matematika siswa dengan menggunakan model pembelajaran kooperatif tipe NHT dan hasil belajar matematika siswa dengan pembelajaran konvensional.

Berdasarkan pengalaman yang diperoleh peneliti selama pembelajaran kooperatif tipe NHT berlangsung, walaupun pada mulanya siswa belum terlihat aktif 
dan kebingungan ketika mengerjakan LKS dan lembar soal NHT akan tetapi pada pertemuan-pertemuan berikutnya mereka sudah menunjukkan keaktifannya dalam belajar dan juga dapat menyelesaikan LKS dan lembar soal NHT lebih cepat dari pertemuan-pertemuan sebelumnya. Dalam pembelajaran kooperatif tipe NHT guru akan memanggil nomor secara acak tanpa memberi tahu terlebih dahulu siapa yang akan mewakili kelompoknya dan mendorong keterlibatan total semua siswa dan merupakan upaya yang sangat baik untuk meningkatkan tanggung jawab individual dalam diskusi kelompok sehingga dapat meningkatkan hasil belajar siswa.

Ada beberapa hal yang menyebabkan hasil belajar matematika siswa di kelas eksperimen lebih baik dari pada hasil belajar matematika siswa dikelas kontrol, antara lain:

1. Pada kelas eksperimen guru membagi siswa dalam kelompok kecil yang terdiri dari 6 kelompok dimana satu kelompok terdiri dari lima sampai enam orang yang memiliki kemampuan yang heterogen. Siswa yang memiliki kemampuan yang tinggi dapat membantu temannya yang berkempuan sedang dan rendah dalam proses pembelajaran dengan alasan tanggung jawab dalam kelompok, dengan kegiatan tersebut tentunya berdampak baik dalam meningkatkan hasil belajar siswa. Sedangkan pada kelas kontrol siswa belajar secara langsung dan individual. Sehingga anak yang berkemampuan tinggi tidak ada keharusan memberikan bantuan kepada siswa yang berkemampuan sedang dan rendah.

2. Pada kelas eksperimen guru memanggil nomor siswa secara acak dan guru tanpa memberi tahu terlebih dahulu siapa yang akan mewakili kelompok. Hal tersebut akan membuat keterlibatan total semua siswa untuk mempersiapkan anggota kelompoknya agar mengetahui jawaban dari soal yang diberikan dan itu merupakan upaya yang sangat baik untuk meningkatkan tanggung jawab individual dalam diskusi kelompok. Sedangkan pada kelas kontrol siswa belajar secara individual.

3. Di dalam kelas eksperimen, interaksi antar siswa lebih besar dibandingkan interaksi siswa dengan guru. Hal ini menyebabkan siswa termotivasi belajar dan bertanya karena yang dihadapinya adalah teman sebayanya. Sedangkan pada kelas kontrol, interaksi siswa dengan guru lebih besar dibandingkan interaksi siswa dengan siswa. Siswa yang belum paham kadang tidak berani untuk bertanya pada guru. 
4. Pada kelas eksperimen di setiap pertemuan guru memberikan penghargaan kepada kelompok yang mempresentasikan. Hal ini membuat setiap kelompok lebih termotivasi untuk mendapatkan nilai yang terbaik.

Analisis data yang digunakan dalam penelitian ini adalah analisis deskriptif dan analisis inferensial. Berdasarkan analisis data tentang hasil belajar matematika siswa pada pokok bahasan perbandingan dan aritmatika sosial menunjukkan rata-rata hasil belajar siswa pada kelas eksperimen dengan menggunakan model pembelajaran Kooperatif Tipe Numbered Head Together (NHT) lebih tinggi dari pada hasil belajar matematika siswa pada kelas kontrol yang menggunakan model pembelajaran konvensional. Perbandingan rata-rata nilai hasil belajar matematika siswa dapat dilihat pada gambar diagram berikut:

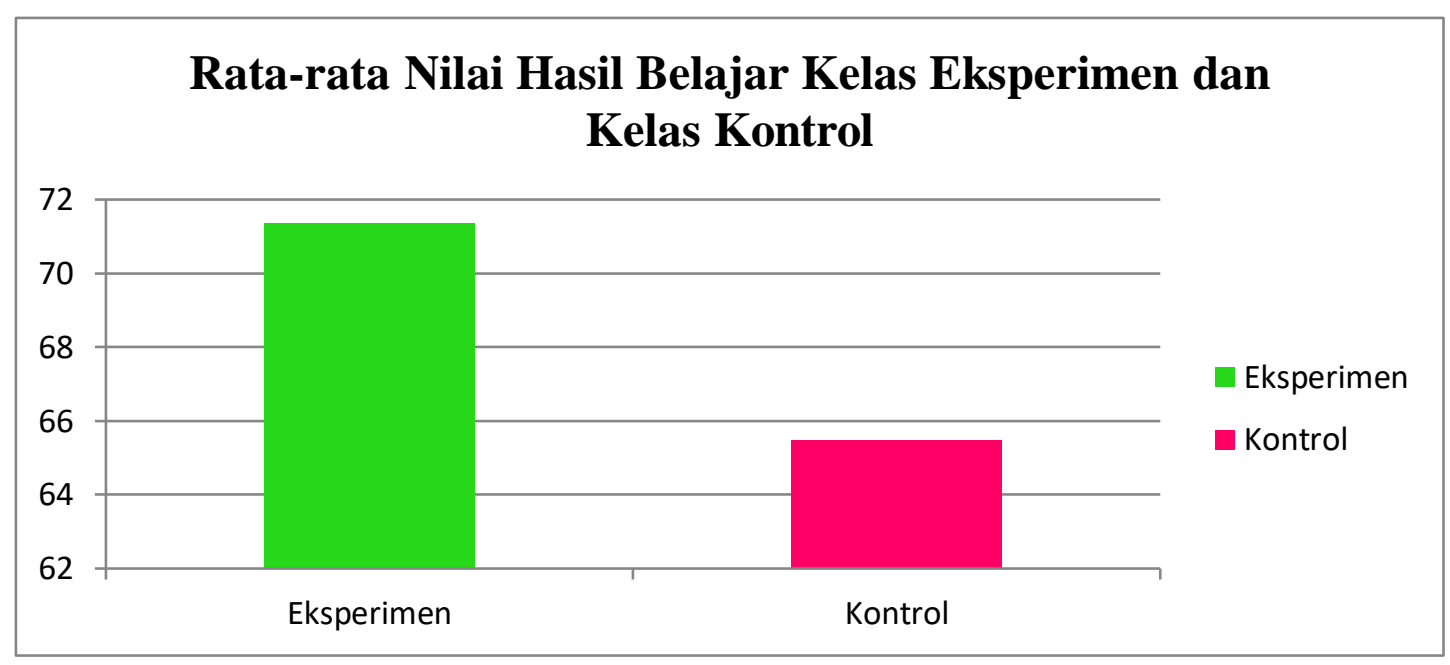

Gambar 1.Perbandingan Nilai Hasil Belajar Matematika Siswa Kelas Eksperimen dan Kelas Kontrol

Berdasarkan gambar diatas menunjukkan bahwa penerapan model pembelajaran Kooperatif Tipe Numbered Head Together (NHT) dalam pembelajaran matematika berpengaruh positif terhadap hasil belajar matematika, dengan demikian hasil analisis ini mendukung hipotesis penelitian yang menyatakan terdapat pengaruh model pembelajaran Kooperatif Tipe Numbered Head Together (NHT) terhadap hasil belajar matematika siswa kelas VII SMP Negeri 1 Bangkinang.

\section{KESIMPULAN}


Berdasarkan hasil analisis data penelitian dengan menggunakan uji-t dimana $t_{\text {hitung }}=$ $2,01>t_{\text {tabel }}=1,67$. Maka dapat disimpulkan bahwa terdapat pengaruh yang signifikan antara hasil belajar matematika siswa kelas eksperimen yang menggunakan model pembelajaran kooperatif tipe NHT dengan hasil belajar matematika siswa kelas kontrol yang menerapkan metode konvensional.

Berdasarkan simpulan dan pembahasan hasil penelitian di atas, maka peneliti memberikan saran yang berhubungan dengan model pembelajaran kooperatif tipe NHT sebagai berikut:

1. Menerapkan model pembelajaran kooperatif tipe NHT ini, agar dapat memperhatikan waktu dengan baik dalam proses kegiatan pembelajaran dan lebih mengontrol siswa pada saat memulai diskusi agar tidak terjadi keributan, dengan demikian permasalahan dalam penelitian ini dapat teratasi.

2. Dalam pembelajaran kooperatif tipe NHT, guru hendaknya dapat memberikan motivasi yang lebih kepada siswa agar dapat mengikuti proses pembelajaran dengan baik dan besungguhsungguh.

3. Bagi peneliti lain yang ingin menggunakan model pembelajaran kooperatif tipe NHT, diharapkan lebih banyak membaca referensi yang lain, agar kelemahan yang terdapat pada penelitian ini dapat teratasi.

\section{UCAPAN TERIMA KASIH}

Terimakasih peneliti ucapkan kepada Bapak Dekan Fakultas Ilmu Pendidikan, Ketua Prodi Pendidikan Matematika yang telah memberikan izin kepada peneliti untuk melakukan penelitian. Terimakasih peneliti juga sampaikan kepada Kepala Sekolah SMA Negeri 1 Bangkinang Kota, serta guru mata pelajaran matematika yang telah memberikan kesempatan kepada peneliti untuk melakukan penelitian di SMA Negeri 1 Bangkinang Kota.

\section{DAFTAR PUSTAKA}

Gintings, Abdorrakhman. (2008). Belajar dan Pembelajaran. Yogyakarta: Humaniora

Huda, Miftahul. (2013). Cooperative Learning. Yogyakarta: Pustaka Pelajar

Ibrahim, Muslimin, dkk. (2010).Pembelajaran Kooperative. Surabaya: Unesa university

Jumariati, Erni. (2012). Pengaruh Penerapan Model Pembelajaran Kooperatif Pendekatan Struktural Numbered Heads Together (NHT)Terhadap Hasil Belajar Matematika Siswa Kelas VIII SMP Negeri 18 Pekanbaru. Pekanbaru: UR 
Lie, Anita. (2002). Cooperative Learning. Jakarta: Grasindo

Mudjiono \& Dimyati. (2006). Belajar dan Pembelajaran. Jakarta: PT Rineka Cipta

Mu'nimah, Nurul. (2012). Pengaruh Pembelajaran Cooperative Tipe Numbered Heads Together (NHT) Terhadap Prestasi Belajar Matematika Materi Bangun Ruang Siswa Kelas VIII SMPN 1 Ngunut Tulungagung. Tulungagung: STAIN

Omar, Ismahera. (2013). Pengeruh Model Pembelajaran Kooperative Tipe Numbered Head Together (NHT) Untuk Meningkatkan Hasil Belajar Matematika Siswa Kelas VIII SMPN 36 Pekanbaru. UR

Sanjaya, Wina. (2012). Perencanaan dan Desain Sistem Pembelajaran. Jakarta: Kencana

Setyosari, P. (2013). Metode Penelitian Pendidikan dan Pengembangan (Edisi Ketiga). Jakarta: Kencana Prenada Media Group

Slameto. (2010). Belajar dan Faktor-faktor yang Mempengaruhinya. Jakarta: Rineka Cipta

Slavin, Robert E. (2005). Cooperative Learning: Theory, Risearch, and, Praktice. Bandung: Penerbit Nusa Media

Sudijono, Anas. (2007). Pengantar Statistik Pendidikan. Jakarta: PT Praja Grafindo Persada

Sudjana. (2005). Metode Statistika. Bandung: Tarsito Bandung

Sudjana, Nana. (2009). Penelitian Hasil Proses Belajar Mengajar. Bandung: PT Remaja Rosda Karya

Sugiyono. (2011). Statistika Untuk Penelitian. Bandung: Alfabeta

Suiyono. (2012). Metode Penelitian Pendidikan Pendekata Kuantitatif dan Kualitatif. Bandung: Alfabeta

Suprijono, Agus. (2010). Cooperative Learning. Yogyakarta: Pustaka Pelajar

Tirtarahardja, Umar. (2008). Pengantar Pendidikan. Jakarta: PT Rineka Cipta

Trianto. (2011). Mendesain Model Pembelajaran Inovatif - progresif. Jakarta: Kencna Prenada Media Group

Usman, Husaini. (1995). Pengantar statistik. Yogyakarta: Bumi Aksara 